\title{
Metformin versus Placebo in Obese Pregnant Women without Diabetes
}

\section{Citation}

Stanford, Fatima C., Nasreen Alfaris, and Madhusmita Misra. "Metformin versus Placebo in Obese Pregnant Women without Diabetes." N Engl J Med 374 (2016): 434-43.

\section{Published Version}

doi:10.1056/NEJMc1603067

\section{Permanent link}

http://nrs.harvard.edu/urn-3:HUL.InstRepos:34853162

\section{Terms of Use}

This article was downloaded from Harvard University's DASH repository, and is made available under the terms and conditions applicable to Other Posted Material, as set forth at http:// nrs.harvard.edu/urn-3:HUL.InstRepos:dash.current.terms-of-use\#LAA

\section{Share Your Story}

The Harvard community has made this article openly available.

Please share how this access benefits you. Submit a story.

\section{Accessibility}




\section{Metformin versus Placebo in Obese Pregnant Women without Diabetes}

TO THE EDITOR: Syngelaki et al. (Feb. 4 issue) ${ }^{1}$ describe the efficacy of metformin in reducing gestational weight gain in women with a bodymass index (BMI; the weight in kilograms divided by the square of the height in meters) of more than 35. Although their study does not show a reduction in the neonatal birth weight, their results underscore the ability of metformin to reduce gestational weight gain in women with moderate-to-severe obesity without diabetes.

One question is whether the exclusion of patients who were started on insulin after the oral glucose-tolerance test would alter the results of the study. Another question is whether a larger sample size would result in significant results for the proportion of women with miscarriages, premature births, or live births across groups. Studies have shown that metformin is safe during pregnancy, with efficacy in treating gestational diabetes mellitus and the polycystic ovary syndrome, and that the drug has no effect on the growth of several cancers. ${ }^{2,3}$ It would be interesting if the authors of this and concurrent studies were to consider whether the use of metformin during pregnancy in women who are obese (BMI, $>30)$ and those who are not obese (BMI, $\leq 30)$ would decrease weight retention after birth. ${ }^{1,4}$ Postpartum weight retention contributes to obesity in all weight classes, and the use of metformin would be an attractive option to reduce this risk. ${ }^{5}$

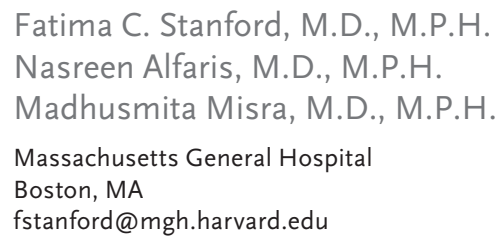

No potential conflict of interest relevant to this letter was reported.

1. Syngelaki A, Nicolaides KH, Balani J, et al. Metformin versus placebo in obese pregnant women without diabetes mellitus. N Engl J Med 2016;374:434-43.

2. Glueck CJ, Wang P, Kobayashi S, Phillips H, Sieve-Smith L. Metformin therapy throughout pregnancy reduces the development of gestational diabetes in women with polycystic ovary syndrome. Fertil Steril 2002;77:520-5.

3. Sivalingam VN, Myers J, Nicholas S, Balen AH, Crosbie EJ. Metformin in reproductive health, pregnancy and gynaecological cancer: established and emerging indications. Hum Reprod Update 2014;20:853-68.

4. Chiswick C, Reynolds RM, Denison F, et al. Effect of metfor- min on maternal and fetal outcomes in obese pregnant women (EMPOWaR): a randomised, double-blind, placebo-controlled trial. Lancet Diabetes Endocrinol 2015;3:778-86.

5. Endres LK, Straub H, McKinney C, et al. Postpartum weight retention risk factors and relationship to obesity at 1 year. Obstet Gynecol 2015;125:144-52.

DOI: 10.1056/NEJMc1603067

TO THE EDITOR: Regarding the use of metformin in obese pregnant women without diabetes mellitus: the fetal period is a time during which exposure to drugs and chemicals that are normally not harmful may initiate processes that ultimately result in adult diseases. We do not have enough long-term data about adults who have had fetal exposure to metformin, which is an endocrine disrupter. It has been reported that exposure to metformin during fetal life is associated with increased rates of high blood pressure and hyperglycemia in children at the age of 8 years. ${ }^{1}$ Tartarin et al. reported that metformin may have harmful effects on the human testis in fetal life. ${ }^{2}$ We know that metformin reduces the levels of folate and vitamin $\mathrm{B}_{12}{ }^{3}$ Deficiencies in folate and vitamin $B_{12}$ may retard growth and brain development. ${ }^{4}$ Since we have safer options for the treatment of diabetes during pregnancy, we would be reluctant to use metformin in pregnant patients without diabetes. Until substantial benefits are proved, we believe it is better to recommend proper diet, exercise routines, and regular prenatal care without medication.

Mustafa Sahin, M.D.

Demet Corapcioglu, M.D.

Ankara University School of Medicine

Ankara, Turkey

drsahinmustafa@yahoo.com

No potential conflict of interest relevant to this letter was reported.

1. Rø TB, Ludvigsen HV, Carlsen SM, Vanky E. Growth, body composition and metabolic profile of 8-year-old children exposed to metformin in utero. Scand J Clin Lab Invest 2012;72:570-5.

2. Tartarin P, Moison D, Guibert E, et al. Metformin exposure affects human and mouse fetal testicular cells. Hum Reprod 2012;27:3304-14.

3. Sahin M, Tutuncu NB, Ertugrul D, Tanaci N, Guvener ND. Effects of metformin or rosiglitazone on serum concentrations of homocysteine, folate, and vitamin B12 in patients with type 2 diabetes mellitus. J Diabetes Complications 2007;21:118-23.

4. Finkelstein JL, Layden AJ, Stover PJ. Vitamin B-12 and perinatal health. Adv Nutr 2015;6:552-63.

DOI: $10.1056 / N E J M c 1603067$ 
THE AUTHORS REPLY: In response to Stanford et al.: after the exclusion of patients receiving insulin, the median gestational weight gain among the women in our study was lower in the metformin group than in the placebo group $(4.6 \mathrm{~kg}$ [interquartile range, 1.3 to 7.2 ] vs. $6.3 \mathrm{~kg}$ [interquartile range, 2.9 to 9.2 ], $\mathrm{P}<0.001$ ). In an evaluation of changes in postpartum weight from the initial antenatal visit, the median gestational weight loss was higher in the metformin group than in the placebo group (1.9 kg [interquartile range, -5.1 to 0.2 ] vs. $0 \mathrm{~kg}$ [interquartile range, -3.9 to 1.5$], \mathrm{P}=0.02$ ). We agree that metformin might reduce the risk of long-term obesity in these women.

In response to Sahin and Corapcioglu: the American Diabetes Association classifies metformin as a category B drug (i.e., no evidence of risk in humans) during pregnancy. In the United Kingdom, metformin is recommended by the National Institute for Health and Care Excellence. ${ }^{1}$ There is no evidence of an increase in congenital malformations (including testicular abnormalities or defects in growth or motor development) in babies born to mothers treated with metformin. ${ }^{2,3}$ Blood-pressure results in a large cohort of 2-year-old children showed no differences between those whose mothers had received insulin and those whose mothers had received metformin. ${ }^{4}$ Active $\mathrm{B}_{12}$ (holotranscobalamin) and methylmalonic acid are better measures of vitamin $B_{12}$ status than are serum levels and do not appear to be pathologically altered in patients with type 2 diabetes after metformin treatment. $^{5}$

Jyoti Balani, M.D.

Steve Hyer, M.D.

Hassan Shehata, M.D.

Epsom and St. Helier University Hospitals NHS Trust London, United Kingdom hassan.shehata@nhs.net

Since publication of their article, the authors report no further potential conflict of interest.

1. National Institute for Health and Care Excellence. Diabetes in pregnancy: management from preconception to the postnatal period. August 2015 (https://www.nice.org.uk/guidance/ng3).

2. Bolton S, Cleary B, Walsh J, Dempsey E, Turner MJ. Continuation of metformin in the first trimester of women with polycystic ovarian syndrome is not associated with increased perinatal morbidity. Eur J Pediatr 2009;168:203-6.

3. Cassina $M$, Donà $M, D i$ Gianantonio $E$, Litta $P$, Clementi $M$. First-trimester exposure to metformin and risk of birth defects: a systematic review and meta-analysis. Hum Reprod Update 2014;20:656-69.

4. Battin MR, Obolonkin V, Rush E, Hague W, Coat S, Rowan J. Blood pressure measurement at two years in offspring of women randomized to a trial of metformin for GDM: follow up data from the MiG trial. BMC Pediatr 2015;15:54.

5. Obeid R, Jung J, Falk J, et al. Serum vitamin B12 not reflecting vitamin B12 status in patients with type 2 diabetes. Biochimie 2013;95:1056-61.

DOI: $10.1056 /$ NEJMc1603067

\section{Transient Smartphone "Blindness"}

TO THE EDITOR: Transient monocular vision loss is a common clinical presentation, and the cause is not always thromboembolic. ${ }^{1}$ We present two cases in which careful history taking established a benign cause (for the case histories, see the Supplementary Appendix, available with the full text of this letter at NEJM.org).

A 22-year-old woman presented with a several months' history of recurrent impaired vision in the right eye that occurred at night. The results of ophthalmic and cardiovascular examinations were normal. Vitamin A levels and the results of magnetic resonance angiography, echocardiography, and a thrombophilia screening were also normal.

The second case involved a 40-year-old woman who presented with a 6-month history of recurrent monocular visual impairment on waking, lasting up to 15 minutes. The results of investigations for a vascular cause were again normal. Aspirin therapy had been commenced.

When the patients were seen in our neuroophthalmic clinic, detailed history taking revealed that symptoms occurred only after several minutes of viewing a smartphone screen, in the dark, while lying in bed (before going to sleep in the first case and after waking in the second). Both patients were asked to experiment and record their symptoms. They reported that the symptoms were always in the eye contralateral to the side on which the patient was lying.

We hypothesized that the symptoms were due 